\title{
Different leaf extracts from Brunfelsia uniflora in mice
}

\author{
Ciro José Sousa de Carvalho $^{1}$ Marília Martins Melo ${ }^{2 *}$ Ana Flávia Ribeiro Machado Michell $^{3}$ \\ Bruno Benetti Junta Torres ${ }^{2}$ Franklin Riet-Correa ${ }^{4}$ Roberto Maurício Carvalho Guedes ${ }^{2}$ \\ Vany Perpetua Ferraz ${ }^{5}$ Benito Soto-Blanco ${ }^{2}$ Silvana Maria Medeiros de Sousa Silva ${ }^{1}$
}

\footnotetext{
${ }^{1}$ Departamento de Clínica e Cirurgia Veterinárias, Universidade Federal do Piauí (UFPI), Teresina, PI, Brasil.

${ }^{2}$ Departamento de Clínica e Cirurgia Veterinárias, Universidade Federal de Minas Gerais (UFMG), Avenida Antônio Carlos, 6626, 31270-901, Belo Horizonte, MG, Brasil. E-mail: mariliamm@ufmg.br. "Corresponding author.

${ }^{3}$ Departamento de Ciências Agrárias, Universidade Estadual de Santa Cruz (UESC), Ilhéus, BA, Brasil.

${ }^{4}$ Universidade Federal de Campina Grande (UFCG), Patos, PB, Brasil.

${ }^{5}$ Departamento de Química, Laboratório de Cromatografia, Universidade Federal de Minas Gerais (UFMG), Belo Horizonte, MG, Brasil.
}

\begin{abstract}
In Brazil, at least 16 poisonous plant species can affect the central nervous system of livestock. Recently in the state of Piaui, Northeastern Brazil, Brunfelsia uniflora was reported as a cause of nervous signs in donkeys, cattle, and small ruminants. In order to assess the toxicity of B. uniflora extracts, 20 Swiss mice were distributed into four groups ( $n=5)$ receiving by gavage alkaloids, flavonoids, saponins, or saline (control group). After administration of the extracts in a single dose $\left(5 \mathrm{~g} \mathrm{~kg}^{-1}\right)$, all mice were observed daily for clinical signs. Mice that received the extracts showed moderate to severe clinical signs, including piloerection, vocalization, and seizures. All mice dosed with saponins died between 10 and 20 min after administration. Serum biochemical evaluation of animals that received saponins revealed slight increases in total protein levels and decreased magnesium and chlorite levels. In conclusion, saponins of B. uniflora leaves induced acute toxic neurological effects and death in mice.
\end{abstract}

Key words: toxicity, alkaloids, saponins, flavonoids, Brunfelsia, Solanaceae.

Diferentes extratos das folhas de Brunfelsia uniflora em camundongos

RESUMO: No Brasil, pelo menos 16 espécies de plantas tóxicas podem afetar o sistema nervoso central dos bovinos. Recentemente no estado do Piaui, no Nordeste do Brasil, Brunfelsia uniflora foi relatada como causadora de sinais nervosos em jumentos, bovinos e pequenos ruminantes. Para avaliar a toxicidade de B. uniflora, 20 camundongos foram distribuidos em quatro grupos de cinco animais recebendo diferentes extratos da planta. Os extratos de alcalóides, flavonóides, saponinas ou solução salina (grupo controle) foram administrados por gavagem. Após a administração dos extratos, em dose única (5g $\mathrm{kg}$-1), todos os animais foram observados diariamente. Os camundongos que receberam os extratos de B. uniflora apresentaram sinais clínicos moderados a graves, incluindo piloeração, vocalização e convulsões. Todos os camundongos que receberam extrato de saponinas morreram entre 10 e 20 minutos após. A avaliação bioquímica sérica dos animais que receberam saponinas, revelou discretos aumentos nos niveis de proteína total e diminuição nos níveis de magnésio e cloro. Conclui-se que, as saponinas presentes nas folhas de B. uniflora induzem efeitos neurológicos tóxicos agudos e, morte em camundongos.

Palavras-chave: toxicidade, alcaloides, saponinas, flavonoides, Brunfelsia, Solanaceae.

\section{INTRODUCTION}

Brunfelsia is a genus of plants belonging to the Solanaceae family, with 40 different native species reported in South America, Central America, and West India. Accidental poisoning by Brunfelsia leaves has been described in humans and dogs after ingestion of the plant grown in gardens.
Clinical signs of poisoning include diarrhea, ataxia, anxiety, vomiting, seizures, tremors, hyperesthesia, nystagmus, and polyuria (SPAINHOUR et al., 1990; SINGH et al., 2008).

A recent survey conducted in the North mesoregion of Piauí identified B. uniflora as a toxic plant species; however, there are no thorough scientific studies of the toxicity of this plant in Brazil. 
Some anecdotal reports by farmers are referred to intoxicate donkeys and cattle, causing nervous signs such as loss of balance and tremors that recover after removal of the animals from areas infested by this plant (MELLO et al., 2010). Experimental studies demonstrated that the leaves of $B$. uniflora were poisonous in sheep and donkeys (MELLO, 2013) and those of B. pauciflora were toxic in cattle (TOKARNIA et al., 1991).

Compounds responsible for the toxicity of B. uniflora leaves are still unknown. Alkaloids (BEKKOUCHE et al., 2001) and flavonoid components (BRUNNER et al., 2000), as well as their pharmacological activity, have already been identified in plants from the genus Brunfelsia.

The objective of the present study was to carry out a phytochemical study of the leaves of $B$. uniflora and evaluate its clinical and anatomo-histopathological profile after oral administration of different extracts using the mouse as experimental animal model.

\section{MATERIALS AND METHODS}

\section{Plant material and extracts}

The leaves of B. uniflora (Pohl.) D. Don (Figure 1) were collected at Caraúbas County of Piauí, located within latitude $03^{\circ} 28^{\prime} 33^{\prime}$ "south and longitude $41^{\circ} 50^{\prime} 35^{\prime}$ ' west, with an altitude of 50 meters. A voucher specimen of the plant was authenticated and deposited in the Graziela Barroso herbarium of the Universidade Federal do Piauí (TEPB 27.957).

Two hundred grams of dried and triturated leaves of B. uniflora were extracted using $1000 \mathrm{ml}$ of water with $1 \mathrm{M} \mathrm{HCl}(\mathrm{pH} 1)$ in an ultrasonic bath for $60 \mathrm{~min}$ at $40^{\circ} \mathrm{C}$. The extract was filtered through cotton and paper filter at vacuum. Two hundred milliliters of $1 \mathrm{M} \mathrm{HCl}$ was added to the resulting solute and a new extraction was performed in ultrasonic bath for $30 \mathrm{~min}$. After further filtration, the extract was identified within the acidic aqueous layer (AAL). This layer was fractionated by partitioning (i.e., through solvent extraction by adding $1000 \mathrm{ml}$ of AAL and $300 \mathrm{ml}$ of

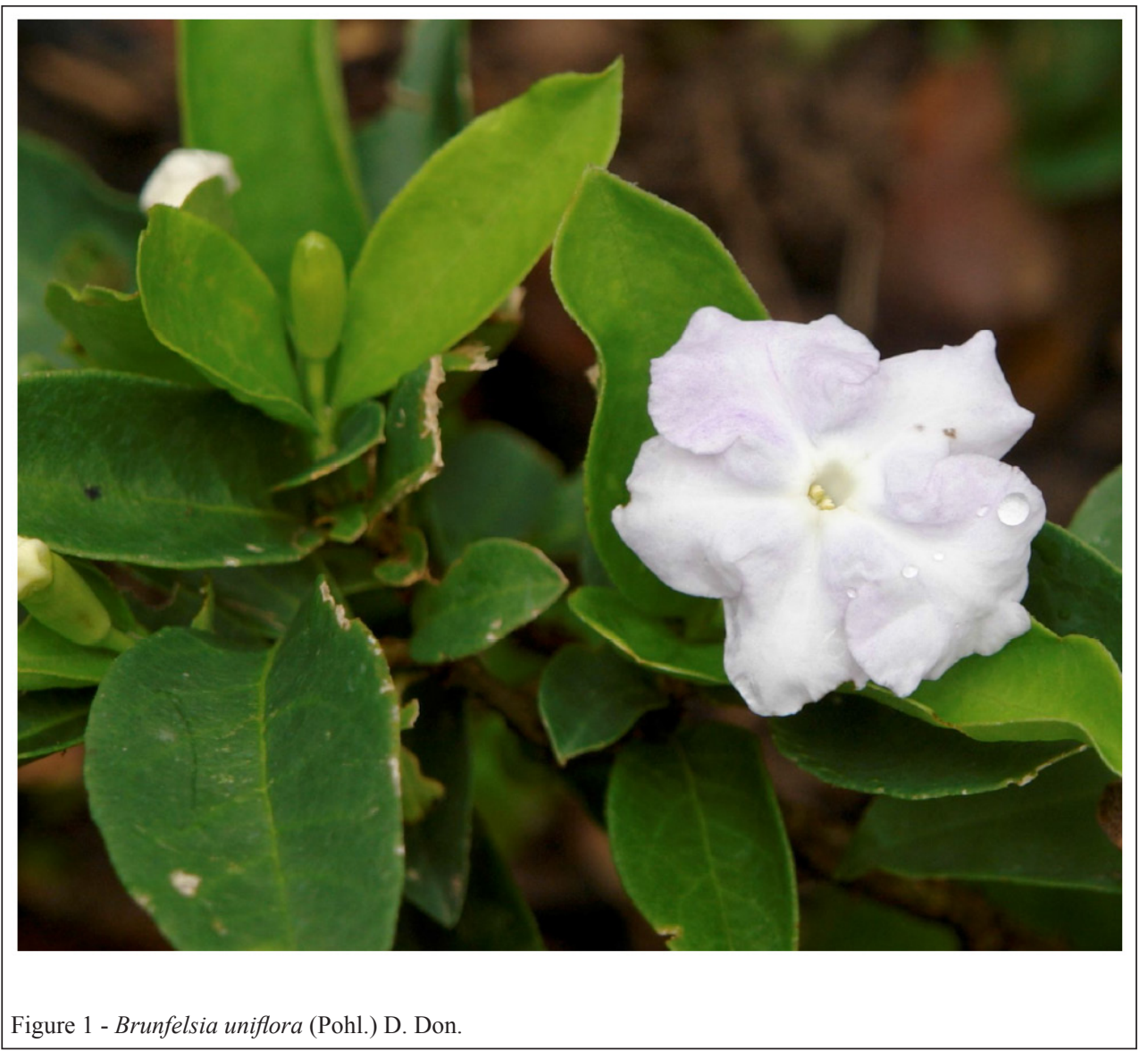

Ciência Rural, v.48, n.1, 2018. 
ethyl acetate). After vigorous agitation and subsequent settling, an organic layer 1 (OL1) and an acidic aqueous layer 1 (AAL1) were obtained. The OL1 was dried by rotary evaporation at $40^{\circ} \mathrm{C}$, and redissolved in $10 \mathrm{ml}$ of water ( $\mathrm{pH} 6.0)$ resulting in the saponins-rich extract. The AAL1 was then basified with $70 \mathrm{ml}$ of ammonium hydroxide and $300 \mathrm{ml}$ of ethyl acetate were added. After vigorous agitation and settling, a second organic layer 2 (OL2) and basic aqueous layer (BAL) were obtained. The OL2 was removed and a second partition was performed by adding $200 \mathrm{ml}$ of ethyl acetate. The obtained organic layer was grouped together with $\mathrm{OL} 2$, and washed twice with $50 \mathrm{ml}$ of water/1M HCl, and these aqueous layers were discarded. OL2 was dried by rotary evaporation and redissolved in $10 \mathrm{ml}$ of water ( $\mathrm{pH}$ 6.0), resulting in the alkaloids-rich extract. We added $500 \mathrm{ml}$ of $1 \mathrm{M}$ ammonium hydroxide $(\mathrm{pH}$ 9.0 ) and $200 \mathrm{ml}$ of methanol to the precipitate derived from the acid aqueous extract. The extraction was done in the ultrasonic bath for $60 \mathrm{~min}$ at $40^{\circ} \mathrm{C}$. The extract was then filtered through cotton and paper filters using a vacuum. Two hundred milliliters of $1 \mathrm{M} \mathrm{NH} \mathrm{NH}_{4} \mathrm{OH}$ was added to the precipitate was added and a new extraction in ultrasonic bath for 30min was performed. After further filtration, the basic aqueous layer 1 (BAL1) was obtained. This was acidified with $\mathrm{HCl}(\mathrm{pH} 1.0)$ and the partition performed with $300 \mathrm{ml}$ of ethyl acetate using separatory funnel. After vigorous agitation and settling, a third organic layer 3 (OL3) 2 and an acidic aqueous layer (AAL2) were obtained. The OL3 was removed and a second partition was performed by adding $200 \mathrm{ml}$ of ethyl acetate. The obtained organic layer was grouped together with OL3 and washed twice with $50 \mathrm{ml}$ of water $/ 1 \mathrm{M} \mathrm{HCl}$, and these aqueous layers were discarded. OL 3 was dried by rotary evaporation at $40^{\circ} \mathrm{C}$ and redissolved in $10 \mathrm{ml}$ of water ( $\mathrm{pH}$ 6.0), resulting in the flavonoids-rich extract.

The composition of each fraction was confirmed according to MAHMOUD et al. (1994). Chromatographic profile of each fraction of the aqueous extract was obtained by High Performance Liquid Chromatography (HPLC). Shimadzu Liquid Chromatography 20A series, equipped with UV-Vis detector, Rheodyne injection valve of $20 \mu \mathrm{l}$ and LC solutions software (Shimadzu). Hypersil ODS column of $250 \times 4.6 \mathrm{~mm}$ (Supelco). Chromatographic conditions for analysis of each extract were: Saponins-rich extract - isocratic elution, methanol/water (10:90), detection at $210 \mathrm{~nm}$ and 254nm (Figure 2A); Alkaloids-rich extract - isocratic elution, methanol/water (30:70), detection at $254 \mathrm{~nm}$ and 280nm (Figure 2B); Flavonoids-rich extract - gradient elution from
$0 \% \mathrm{~A}$ to $100 \% \mathrm{~A}$ in $30 \mathrm{~min}$, where $\mathrm{A}$ is methanol and $\mathrm{B}$ is phosphate buffer $\mathrm{pH}$ 4.5, detection at $370 \mathrm{~nm}$ (Figure 2C) (He, 2000). All extracts contained more than $90 \%$ of compounds from the respective chemical group (saponins, alkaloids and flavonoids). Before administration to animals, all extracts were suspended in water, adjusted to $\mathrm{pH}$ 6.0 , and maintained at a ratio of $20 \mathrm{~g}$ of $B$. uniflora leaves to $1.0 \mathrm{ml}$ of concentrated extract.

\section{Animals and extracts administration}

All procedures, treatments and animal care were approved by the Ethics Committee on Animal Experimentation at the Universidade Federal do Piauí (protocol CEEA - 014/12). Twenty healthy male Swiss mice aged eight weeks and weighting $30 \mathrm{~g}$ were distributed into four groups ( $\mathrm{n}=5$ per group). They were dewormed and kept under a 12/12h light-dark cycle for seven days of acclimation with commercial rodent food and water ad libitum prior to extract administration. The animals were dosed with: flavonoids-rich extract, saponins-rich extract, alkaloids-rich extract, or $0.9 \% \mathrm{NaCl}$ solution (control group). Each extract was given as a single dose of $5 \mathrm{~g}$ $\mathrm{kg}^{-1}$ in a volume of $0.3 \mathrm{ml}$ animal ${ }^{-1}$. Extracts were given via an orogastric tube after a fasting period of two hours. Immediately before the gavage, and after extract administration, all animals were evaluated individually and in groups to describe the clinical signs.

Two hours after extract administration, the mice that survived were anesthetized with $50 \mathrm{mg} \mathrm{kg}^{-1}$ of xylazine associated with $50 \mathrm{mg} \mathrm{kg}^{-1}$ of ketamine intramuscularly. Microhematocrit capillary tubes were used for collecting $0.3 \mathrm{ml}$ of blood from the retro-orbital space. The samples were placed in $1.5-\mathrm{ml}$ micro tubes containing $50 \mu \mathrm{l}$ of $10 \%$ EDTA for complete blood count using a veterinary electronic counting device (ABX-VET, Horiba ABX Diagnostics, Montpellier, France). Moreover, another $1.0 \mathrm{ml}$ of blood from each animal was collected and placed in micro centrifuge tubes without anticoagulant and centrifuged at $800 \times g$ for five minutes to obtain serum. Serum was used for biochemical analysis of alanine aminotransferase (ALT), total proteins, albumin, urea, creatinine, chloride, magnesium, and calcium using specific commercial kits (Bioclin, Belo Horizonte, MG, Brazil) and a biochemical analyzer (TP Analyzer, Thermoplate, China).

\section{Statistical analysis}

Normality of data was checked by the Shapiro-Wilk's test. Parametric data was compared by analysis of variance (ANOVA) followed by 


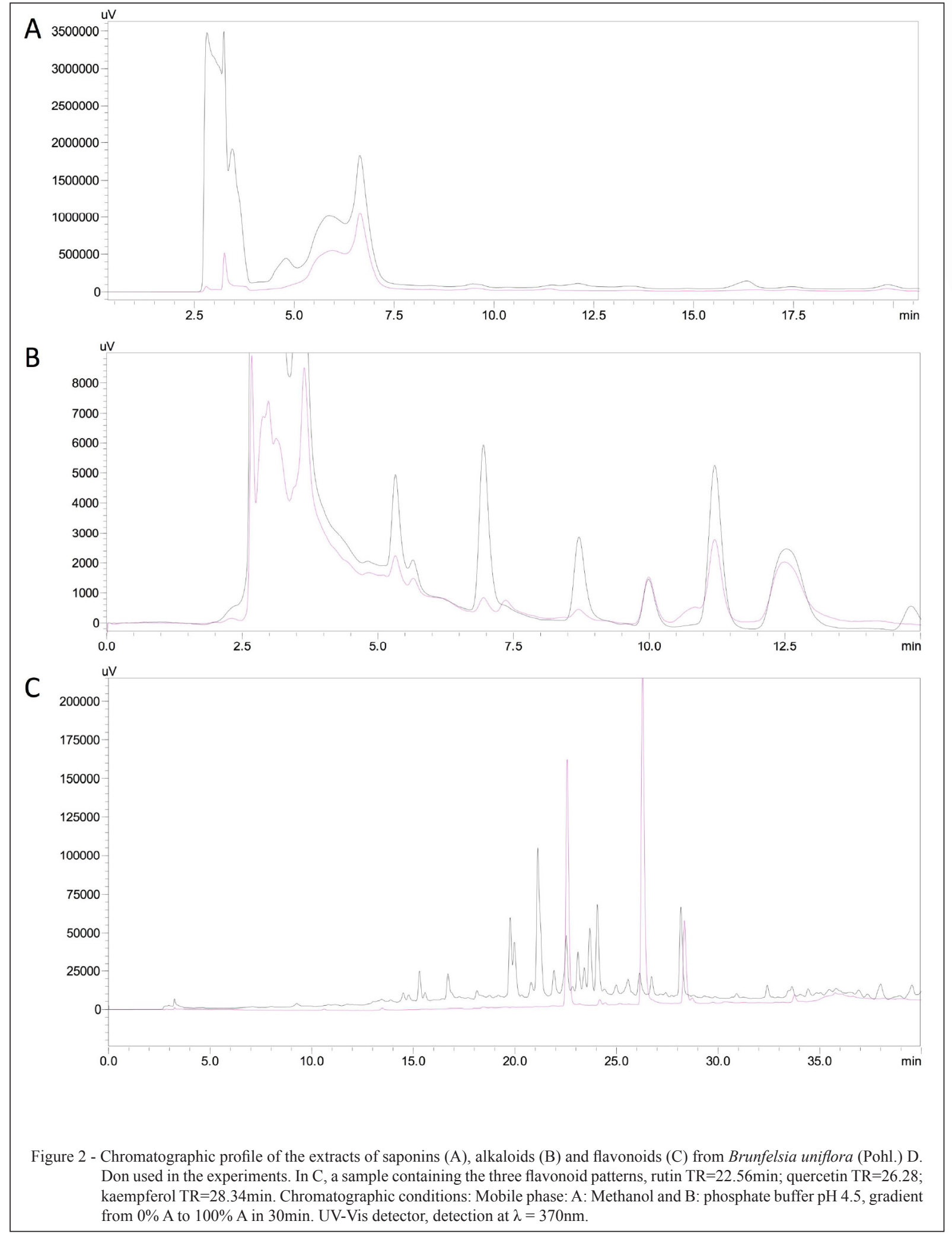

Ciência Rural, v.48, n.1, 2018. 
Tukey's test. Non-parametric data was compared by Kruskal-Wallis'test followed by Student-NewmanKeuls's test. The significance level was set at $\mathrm{P}<0.05$.

\section{RESULTS}

Figure 2A shows the chromatographic profile of the Fraction 1 (saponins): this yielded a strong early peak obtained at $210 \mathrm{~nm}$ (black line) and did not absorb at $254 \mathrm{~nm}$ (pink line), indicating the presence of saponins. Figure $2 \mathrm{~B}$ shows the chromatographic profile of the Fraction 2 (alkaloids): peaks between 10 and $13 \mathrm{~min}$ intensely absorbed both at $254 \mathrm{~nm}$ (black line) and at $280 \mathrm{~nm}$ (pink line), indicating the presence of alkaloids. Figure 2C shows the chromatographic profile of the Fraction 4 (flavonoids): a peak appeared at 370nm (black line) indicating the presence of flavonoids. In addition, a mixture of rutin, quercetin, and kaempferol patterns (pink chromatogram) was eluted in the same region of the chromatogram under the same conditions (UV $370 \mathrm{~nm}$; rutin $\mathrm{TR}=22.56 \mathrm{~min}$; quercetin $\mathrm{TR}=26.28$; kaempferol $\mathrm{TR}=28.34 \mathrm{~min}$ ).

Clinical signs of poisoning induced by different extracts of $B$. uniflora are shown at table 1 . Animals that received the extract of alkaloids showed piloerection, severe seizures and muscle tremors $10 \mathrm{~min}$ after extract administration. In the group dosed with the extract of flavonoids, seizures and moderate piloerection emerged $57 \mathrm{~min}$ post-administration. Five animals that received the extract of saponins died between 10 and 20min post-administration. Neurological signs ranged from moderate to severe, and sudden death occurred most likely from cardiorespiratory arrest. Vocalization was observed in all animals receiving extracts of $B$. uniflora. Mice from the control group did not develop any clinical sign.

The number of platelets was higher $(\mathrm{P}<0.05)$ in control group than in all groups receiving the extracts. Conversely, the values of erythrocytes, packed cell volume, erythrocyte indices $(\mathrm{MCV}, \mathrm{MCH}$, and $\mathrm{MCHC}$ ), and white blood cells in the animals receiving the different extracts of $B$. uniflora did not differ statistically from the control group (Table 2).

Regarding the serum biochemical panel, the group that received saponins showed the highest mean value $(\mathrm{P}<0.05)$ of albumin than other groups (Table 3). Mean creatinine values of the groups that received the alkaloids, flavonoids and saponin extracts were lower than values from control group. Mean levels of calcium were higher $(\mathrm{P}<0.05)$ in control mice than in the group that received the alkaloids-rich extract. The lowest $(\mathrm{P}<0.05)$ mean value of chloride and the highest $(\mathrm{P}<0.05)$ value of magnesium were observed in mice that received the saponins-rich extract. Furthermore, the value for chlorides in the group treated with saponins $\left(35.0 \mathrm{mEq} \mathrm{L}^{-1}\right)$ was below the minimum observed in mice $\left(49.14 \mathrm{mEq} \mathrm{L}^{-1}\right)$, according to SPINELLI et al. (2012).

At pathological examination, no gross or microscopic lesions were observed in the organs of mice after the administration of different extracts from leaves of B. uniflora or saline.

\section{DISCUSSION}

Chromatographic analysis of plant extracts is important for understanding the biological activity and comparison of phytochemical constituents in different samples (LIANG et al., 2004). The present study described for the first time the chromatographic profiles of extracts from leaves of $B$. uniflora. Alkaloids such as scopoletin have been reported in most species of the genus Brunfelsia (MORS \& ROBEIRO, 1957), and the calystegine alkaloids were identified in B. nitida (BEKKOUCHE et al., 2001). A variety of flavonoids have been isolated from species belonging to the Solanaceae family including Browallia grandiflora, Chamaesara chasordida, Nicotiana tabacum, Petunia urfina, and Salpiglossis

Table 1 - Clinical signs and evolution of poisoning induced by different extracts of Brunfelsia uniflora in Swiss mice.

\begin{tabular}{|c|c|c|c|c|c|c|}
\hline Group (Extract) & Animals (n) & Clinical Onset & Seizures & Piloerection & Vocalization & Death \\
\hline G-alkaloids & 5 & $10 \mathrm{~min}$ & +++ & +++ & +++ & 0 \\
\hline G-flavonoids & 5 & $57 \mathrm{~min}$ & ++ & ++ & ++ & 0 \\
\hline G-saponins & 5 & $10 \mathrm{~min}$ & +++ & +++ & +++ & 5 \\
\hline Control Group & 5 & - & - & - & - & 0 \\
\hline
\end{tabular}

Degree of intensity: $(+)$ mild; $(++)$ moderate; $(+++)$ severe. 
Table 2 - Hematological values after administration of different extracts of Brunfelsia uniflora in Swiss mice. Data are show as mean \pm SEM.

\begin{tabular}{|c|c|c|c|c|}
\hline & G-alkaloids & G-flavonoids & G-saponins & Control Group \\
\hline Erythrocytes $\left(\times 10^{6} \mu 1^{-1}\right)$ & $8.96 \pm 0.43$ & $10.42 \pm 0.39$ & $8.91 \pm 0.44$ & $9.46 \pm 0.29$ \\
\hline Hemoglobin $\left(\mathrm{g} \mathrm{dl}^{-1}\right)$ & $14.0 \pm 0.77$ & $16.2 \pm 0.48$ & $13.8 \pm 0.55$ & $14.4 \pm 0.65$ \\
\hline Packed cell volume (\%) & $41.5 \pm 2.37$ & $45.6 \pm 1.29$ & $40.9 \pm 1.54$ & $43.0 \pm 1.26$ \\
\hline $\operatorname{MCV}(\mathrm{fl})$ & $46.2 \pm 1.24$ & $43.6 \pm 0.68$ & $46.0 \pm 1.00$ & $45.5 \pm 0.29$ \\
\hline $\mathrm{MCH}(\mathrm{pg})$ & $15.6 \pm 0.19$ & $15.5 \pm 0.29$ & $15.5 \pm 0.36$ & $15.2 \pm 0.67$ \\
\hline $\mathrm{MCHC}\left(\mathrm{g} \mathrm{dl}^{-1}\right)$ & $33.7 \pm 0.81^{\mathrm{b}}$ & $35.5 \pm 0.29^{\mathrm{a}}$ & $33.6 \pm 0.33^{b}$ & $35.4 \pm 1.55^{\mathrm{a}, \mathrm{b}}$ \\
\hline Platelets $\left(\times 10^{3} \mu 1^{-1}\right)$ & $618.2 \pm 27.7^{\mathrm{b}}$ & $650.8 \pm 39.0^{\mathrm{a}, \mathrm{b}}$ & $527.8 \pm 57.0^{\mathrm{b}}$ & $829.7 \pm 66.1^{\mathrm{a}}$ \\
\hline Leukocytes $\left(\mu 1^{-1}\right)$ & $2,758 \pm 404$ & $3,948 \pm 615$ & $3,454 \pm 335$ & $4,660 \pm 555$ \\
\hline
\end{tabular}

\footnotetext{
${ }^{a, b, c}$ Means followed by different letters in the same row differ statistically $(\mathrm{P}<0.05)$, ANOVA followed by Tukey's test (platelets) or Kruskal-Wallis'test followed by Student-Newman-Keuls's test $(\mathrm{MCHC})$. MCV $=$ mean corpuscular volume, $\mathrm{MCH}=$ mean corpuscular hemoglobin, $\mathrm{MCHC}=$ mean corpuscular hemoglobin concentration.
}

sinuata (WOLLENWEBER \& DORR, 1995). However, there have been no reports of saponins in extracts from B. uniflora. Spectrophotometric methods for the identification of saponins include several types of chromatographies including thin layer, gas, and HPLC. The latter is the best and most used for determination of saponins (OLESZEK, 2002), and we thus employed it in this experiment for the confirmation of saponin presence in B. uniflora.

The finding that $B$. uniflora extracts exhibits toxicity is critical. This is because, besides the harm that this plant causes for donkeys and sheep (MELLO, 2013), its leaves are used to exert antihypertensive, abortive and hallucinogenic effects in people. Indeed, it is used by some native communities and in folk medicine to treat arthritis, rheumatism, syphilis, snake bites, yellow fever, and as a diuretic, laxative, antipyretic, and anesthetic agent (AGRA et al., 2007).

The time of onset of clinical signs in experimental poisoning by $B$. uniflora resembled those observed by SPAINHOUR et al. (1990); the latter group observed the effects with $B$. calcyina beginning at $10 \mathrm{~min}$ in mice and at $60 \mathrm{~min}$ in rats. Piloerection, tremors, seizures, limbs extension, urination, and vocalization were observed in our study, albeit with different intensities. Similar clinical findings were described by SPAINHOUR et al. (1990) when conducting toxicological research with $B$. calcyina var. floribunda, a bush garden reported in the United States. They reported that extracts prepared from the fruit, stem, leaves, and branches of this plant caused anxiety, tremors, seizures, and increased heart rate and breathing without piloerection in mice and rats. In addition to the neurological signs, diarrhea and vomiting have also been reported in poisoned dogs after ingestion of Brunfelsia spp. (SINGH et al., 2008). Notably dogs, but not mice, suffered from diarrhea. The clinical signs observed corroborate the assigned alkaloid outcomes described in the literature (McBARRON \& de SAREM, 1975). Importantly, in this experiment all the extracts were toxic, which proved that toxicity of this plant is not limited to alkaloids; this is in contrast to several previous reports (LLOYD et al., 1985; IYER et al., 1977; WRIGHT, 1982).

The animals receiving saponin extract presented neurological clinical signs that progressed to death. These chemical compounds have lipophilic action that facilitates the formation of complexes of saponins with steroids, proteins and phospholipids from the cell membranes, altering their permeability or causing their destruction (SIMÕES et al., 2010). Besides their cytotoxic capacity, certain types of saponins are potent openers of calcium and potassiumdependent channels in membranes of neurons and muscle cells; this causes hyperpolarization and suppression of electrical activity (McMANUS et al., 1993), which could explain the neurological signs observed in mice receiving saponins.

Other compounds present in B. uniflora are flavonoids, a group of very extensive polyphenolic compounds, due to their great chemical variety and widespread occurrence in the plant kingdom (TERAHARA, 2015). It is largely known that flavonoids exhibitawide beneficial action on biological systems demonstrating antimicrobial, antiviral, 
Table 3 - Serum biochemical profile after administration of different extracts of Brunfelsia uniflora in Swiss mice. Data are show as mean \pm SEM.

\begin{tabular}{|c|c|c|c|c|}
\hline & G-alkaloids & G-flavonoids & G-saponins & Control Group \\
\hline Proteins $\left(\mathrm{g} \mathrm{dl}^{-1}\right)$ & $6.76 \pm 0.13$ & $6.76 \pm 0.12$ & $8.05 \pm 0.53$ & $7.04 \pm 0.07$ \\
\hline $\operatorname{Albumin}\left(\mathrm{g} \mathrm{dl}^{-1}\right)$ & $5.39 \pm 0.07^{\mathrm{a}}$ & $5.15 \pm 0.10^{\mathrm{a}}$ & $6.15 \pm 0.23^{b}$ & $5.48 \pm 0.18^{\mathrm{a}}$ \\
\hline $\operatorname{ALT}\left(\mathrm{U} \mathrm{l}^{-1}\right)$ & $65.0 \pm 5.14$ & $62.8 \pm 10.9$ & $51.2 \pm 1.40$ & $52.0 \pm 2.78$ \\
\hline $\operatorname{Urea}\left(\mathrm{mg} \mathrm{dl}^{-1}\right)$ & $32.9 \pm 2.88$ & $41.9 \pm 9.73$ & $26.1 \pm 3.33$ & $25.8 \pm 1.92$ \\
\hline Creatinine $\left(\mathrm{mg} \mathrm{dl}^{-1}\right)$ & $0.46 \pm 0.02^{\mathrm{a}}$ & $0.61 \pm 0.04^{\mathrm{a}}$ & $0.61 \pm 0.03^{\mathrm{a}}$ & $0.82 \pm 0.09^{b}$ \\
\hline Calcium $\left(\mathrm{mg} \mathrm{dl}^{-1}\right)$ & $3.80 \pm 0.22^{\mathrm{a}}$ & $4.69 \pm 0.23^{b}$ & $4.36 \pm 0.14^{\mathrm{a}, \mathrm{b}}$ & $4.78 \pm 0.17^{b}$ \\
\hline Chloride $\left(\mathrm{mEq} \mathrm{l}^{-1}\right)$ & $79.7 \pm 0.76^{\mathrm{a}}$ & $63.1 \pm 1.60^{\mathrm{b}, \mathrm{c}}$ & $35.0 \pm 7.21^{\mathrm{c}}$ & $67.2 \pm 5.05^{\mathrm{a}, \mathrm{b}}$ \\
\hline Magnesium $\left(\mathrm{mmol} \mathrm{l}^{-1}\right)$ & $1.27 \pm 0.31^{\mathrm{a}}$ & $2.32 \pm 0.29^{\mathrm{a}}$ & $4.68 \pm 0.49^{b}$ & $2.07 \pm 0.46^{\mathrm{a}}$ \\
\hline
\end{tabular}

${ }^{a}, b, c$ Means followed by different letters in the same row differ statistically $(\mathrm{P}<0.05)$, ANOVA followed by Tukey's test (Albumin, Creatinine, Calcium, Magnesium) or Kruskal-Wallis'test followed by Student-Newman-Keuls's test (Chloride). ALT = alanine aminotransferase.

anti-ulcerogenic, anticytotoxic, antineoplastic, anti-oxidant, antihepatotoxic, antihypertensive, anti-inflammatory, and hypolipidemic effects (DWYER \& PETERSON, 1998; PELZER et al., 1998; TERAHARA, 2015). Since this study showed neurological signs in animals that received flavonoid extract, more studies are therefore, needed to identify which flavonoids are present in B. uniflora. The compounds should then be tested separately in vivo to evaluate their true clinical importance.

Mice dosed with saponins showed the highest average value of magnesium $\left(4.68 \mathrm{mmol} \mathrm{l}^{-1}\right)$. Hypermagnesemia can cause breathing depression due to the failure of the respiratory muscles and a cardiotoxic framework; this can lead to cardiac arrest (KANEKO et al., 2008), which would explain the deaths of animals treated with saponins.

Additionally, in the group that received the saponins showed a significant decrease of chloride levels. Chloride is the most abundant anion in the extracellular fluid compartment. Since it is easily transported, chloride contributes to the movement of water and other electrolytes, such as sodium in the distal ileum, proximal colon and loop of Henle (THRALL et al., 2004). Chloride concentration tends to vary inversely with bicarbonate concentration. In metabolic alkalosis, the blood concentration of bicarbonate increases concomitant with a decrease in blood chlorides. Such hypochloremia is a consistent feature of metabolic alkalosis. However, the decreased chloride blood levels can also be seen as part of a compensatory response of a primary chronic respiratory acidosis (KANEKO et al., 2008).
Although, the serum creatinine values in groups dosed with the extracts were lower than in the control group, they were still within normal range values (KANEKO et al., 2008). Furthermore, the serum levels of urea were not affected by dosing the extracts, which indicates that B. uniflora extracts did not cause kidney damage.

In conclusion, we have established that B. uniflora leaves contain alkaloids, flavonoids, and saponins. Administration of different $B$. uniflora extracts at a dose of $5 \mathrm{~g} \mathrm{~kg}^{-1}$ produces acute toxic neurological effects in Swiss mice. The extract rich in saponins was lethal, and this compound class may thus be responsible for toxicity associated with $B$. uniflora extracts.

\section{ACKNOWLEDGMENTS}

This research was financially supported by Instituto Nacional de Ciência e Tecnologia para o Controle das Intoxicações por Plantas and Conselho Nacional de Desenvolvimento Científico e Tecnológico (CNPq), Grant N. 573534/2008-2012.

\section{REFERENCES}

AGRA, M.F. et al. Synopsis of the plants known as medicinal and poisonous in Northeast of Brazil. Revista Brasileira de Farmacognosia, v.17, n.1, p.114-140, 2007. Available from: $<$ http://www.scielo.br/scielo.php?script=sci_arttext\&pid=S0102$695 X 2007000100021 \& \operatorname{lng}=\mathrm{en} \& \mathrm{nrm}=\mathrm{iso}>$. ISSN $0102-695 \mathrm{X}$. Accessed: Jul. 04, 2017. doi: 10.1590/S0102-695X2007000100021.

BEKKOUCHE, $K$. et al. Calystegine distribution in some solanaceous species. Phytochemistry, v.58, n.3, p.455-462, 2001. Available from: <https://doi.org/10.1016/S0031-9422(01)00283-7>. Accessed: Jul. 04, 2017. doi: 10.1016/S0031-9422(01)00283-7. 
BRUNNER, G. et al. A novel acylated flavonol glycoside isolated from Brunfelsia grandiflora ssp. structure elucidation by gradient accelerated NMR spectroscopy at 14T. Phytochemical Analysis, v.11, n.1, p.29-33, 2000. Available from: <http:// dx.doi.org/10.1002/(SICI)1099-1565(200001/02)11:1<29::AIDPCA486>3.0.CO;2-K>. Accessed: Jul. 04, 2017. doi: $10.1002 /(\mathrm{SICI}) 1099-1565(200001 / 02) 11: 1<29:$ :AID PCA486>3.0.CO;2-K.

HE, X.G. On-line identification of phytochemical constituents in botanical extracts by combined high-performance liquid chromatographic-diode array detection-mass spectrometric techniques. Journal of Chromatography A, v.880, n.1-2, p.203232, 2000. Available from: <http://dx.doi.org/10.1016/s00219673(00)00059-5>. Accessed: Jul. 04, 2017. doi: 10.1016/S00219673(00)00059-5.

IYER, R.P. et al. Brunfelsia hopeana I: hippocratic screening and anti-inflammatory evaluation. Lloydia, v.40, p.356-360, 1977.

KANEKO, J.J. et al. Clinical biochemistry of domestic animals. 5.ed. Burlington: ACADEMIC, 2008. 916p.

LIANG, Y. et al. Quality control of herbal medicines. Journal of Chromatography B, Analytical technologies in the biomedical and life sciences, v.812, n.1-2, p.53-70, 2004. Available from: $<$ http://dx.doi.org/10.1016/j.jchromb.2004.08.041>. Accessed: Jul. 04, 2017. doi: 10.1016/j.jchromb.2004.08.041.

LLOYD, H.A. et al. Brunfelsamidine: a novel convulsant from the medicinal plant Brunfelsia grandiflora. Tetrahedron Letters, v.26, n.22, p.2623-2624, 1985. Available from: $<$ https://doi.org/10.1016/ S0040-4039(00)98119-X>. Accessed: Jul. 04, 2017. doi: 10.1016/ S0040-4039(00)98119-X.

MAHMOUD, M. et al. Experimental phytochemistry a laboratory manual. Riyadh: King Saud University, 1994. 143p.

McBARRON, E.J., De SAREM, W. Poisoning of dogs by the fruits of the garden shrub Brunfelsia bonodora. Australian Veterinay Journal, v.51, n.5, p.280, 1975. Available from: $<$ https://doi. org/10.1111/j.1751-0813.1975.tb06950.x>. Accessed: Jul. 04, 2017. doi: 10.1111/j.1751-0813.1975.tb06950.x.

McMANUS, O.B. et al. An activator of calcium-dependent potassium channels isolated from a medicinal herb. Biochemistry, v.32, n.24, p.6128-6133, 1993. Available from: <https://doi. org/10.1021/bi00075a002>. Accessed: Jul. 04, 2017. doi: 10.1021/ bi00075a002.

MELLO, G.W.S. Intoxicação por Brunfelsia uniflora em asininos e ovinos no Piauí. 2013. 55f. Tese (Doutorado em Patologia) Programa de Pós-graduação em Veterinária da Universidade Federal do Piauí, Brasil.

MELLO, G.W.S. et al. Plantas tóxicas para ruminantes e equídeos no Norte Piauiense. Pesquisa Veterinária Brasileira, v.30, n.1, p.1-9, 2010. Available from: <http://www.scielo.br/scielo. php?script=sci_arttext\&pid=S0100-736X2010000100001\&lng
$=$ en\&nrm=iso $>$. ISSN 0100-736X. Accessed: Jul. 04, 2017. doi: 10.1590/S0100-736X2010000100001.

MORS, W.G.; RIBEIRO, O. Occurrence of scopoletin in the genus Brunfelsia. Journal of Organic Chemistry, v.22, n.8, p.978-979, 1957. Available from: <http://dx.doi.org/10.1021/jo01359a601. Accessed: Jul. 04, 2017. doi: 10.1021/jo01359a601.

OLESZEK, W.A. Chromatographic determination of plant saponins. Journal of Chromatography A, v.967, n.1, p.147-162, 2002. Available from: $<$ https://doi.org/10.1016/S0021-9673(01)01556-4>. Accessed: Jul. 04, 2017. doi: 10.1016/S0021-9673(01)01556-4.

PELZER, E.L. Acute and chronic and inflammatory effects of plant flavonoids. II Farmaco, v.3, n.6, p.421-424, 1998. Available from: $<$ https://doi.org/10.1016/S0014-827X(98)00046-9>. Accessed: Jul. 04, 2017. doi: 10.1016/S0014-827X(98)00046-9.

PETERSON, J.; DWYER, J. Flavonoids: Dietary occurrence and biochemical activity. Nutrition Research, v.18, n.12, p.19952018, 1998. Available from: <https://doi.org/10.1016/S02715317(98)00169-9>. Accessed: Jul. 04, 2017. doi: 10.1016/S02715317(98)00169-9.

SIMÕES, C.M.O.; SCHENKEL, E.P.; GOSMANN, G.; MELLO, J.C.P.; MENTZ, L.A.; PETROVICK. P.R. (Orgs). Farmacognosia: da planta ao medicamento. 6.ed. Porto Alegre: Editora da UFRGS: Florianópolis: Editora da UFSC, 2010. 1104p.

SINGH, M. et al. Brunfelsia spp. (Yesterday, today, tomorrow) toxicity in four dogs. Australian Veterinay Journal, v.86, n.6, p.214-218, 2008. Available from: <https://doi. org/10.1111/j.1751-0813.2008.00286.x>. Accessed: Jul. 04, 2017. doi: $10.1111 /$ j.1751-0813.2008.00286.x.

SPAINHOUR, C.B. et al. A toxicological investigation of the garden shrub Brunfelsia calcyina var. floribunda (yesterday-todayand-tomorrow) in three species. Journal of Veterinay Diagnostic Investigation, v.2, n.1, p.3-8, 1990.

SPINELLI, M.O. et al. Comparação dos parâmetros bioquímicos de camundongos criados em diferentes condições sanitárias. Scientia Plena, v.8, n.2, p.1-8, 2012.

TERAHARA, N. Flavonoids in foods: a review. Natural Product Communications, v.10, n.3, 521-528, 2015.

THRALL, M.A. Veterinary hematology and clinical chemistry. Maryland: Lippincott Williams \& Wilkins, 2004. 518p.

TOKARNIA, C.M.A.H. et al. Intoxicação experimental por Brunfelsia pauciflora (Solanaceae) em bovinos. Pesquisa Veterinária Brasileira, v.11, p.9-12, 1991.

WOLLENWEBER, E.; DORR, M. Exudate flavonoids in some Solanaceae. Biochemical Systematics and Ecology, v.23, n.4, p.457-458, 1995. Available from: <https://doi.org/10.1016/03051978(95)00017-O>. Accessed: Jul. 04, 2017. doi: 10.1016/03051978(95)00017-O. 